REVISTA DE DERECHO UNED, NÚM. 26, 2020

\title{
EL CONTROL POLÍTICO DE LA OPINIÓN PÚBLICA EN LA ESPAÑA DE LOS AUSTRIAS
}

\author{
THE POLITICAL CONTROL OF PUBLIC OPINION \\ IN THE SPAIN OF THE AUSTRIA
}

\author{
HÉctor Álvarez García \\ Profesor Ayudante Doctor de Derecho Constitucional \\ Universidad Pablo de Olavide
}

Sumario: 1. La legislación censoria. 2. La génesis de la opinión pública. 3. El adoctrinamiento popular. 3.1. La Nueva Comedia. 3.2. La predicación religiosa. 4. Conclusiones.

Resumen: En el marco de la legislación censoria de la España imperial pretendemos analizar, por una parte, el origen cultural y doctrinal del concepto sociológico de opinión pública en nuestro país, que hunde sus raíces en el absolutismo contrarreformista y fue adoptando una fisonomía reconocible en el seno de la sociedad española del Siglo de Oro, gracias a la contribución de nuestros tratadistas barrocos; y, por otra, la dimensión política y adoctrinadora de la Nueva Comedia y de la predicación religiosa, ya que constituyeron los más efectivos resortes propagandísticos de manipulación de masas impulsados desde el Poder en orden a conseguir la adhesión emocional y, por tanto, irracional del pueblo español al régimen monárquico-señorial de los Austrias.

Abstract: In the framework of the censorship legislation of imperial Spanish we pretend to analyze, on the one hand, the cultural and doctrinal origin of sociological concept of public opinion in our country, which has its roots in counter-reformist absolutism and was adopting a recognizable physiognomy within the spanish so- 
ciety of the Golden Age thanks to the contribution of our baroque writers; and, on the other, the political and indoctrinating dimension of the New Comedy and religious preaching, since they constituted the most effective propaganda springs of mass manipulation driven by the Power in order to achieve emotional accession and, therefore, irrational from the spanish people to the Hispanic monarchy.

Palabras Clave: adoctrinamiento, censura, opinión pública, Siglo de Oro, Nueva Comedia y predicación religiosa.

Key words: indoctrination, censorship, public opinion, Golden Age, New Comedy and religious preaching

Recepción original: 13-01-2020

Aceptación original: 2-6-2020

\section{LA LEGISLACIÓN CENSORIA}

La legislación censoria española no distinguió entre censura gubernativa y eclesiástica hasta finales del siglo XVIII ${ }^{1}$. Estableció "una censura de Estado: el poder civil ejercía una censura previa mediante la concesión de licencias y la Inquisición ejercía una censura "doctrinal" y a posteriori con el examen ulterior de los libros e impresos" 2 .

La política censoria principió con la Pragmática de los Reyes Católicos de 8 de julio de $1502^{3}$. Todas las obras requerían para su impresión licencia real o de ciertas autoridades civiles o religiosas: los presidentes de las Audiencias de Valladolid y Granada, los arzobispos de Toledo, Sevilla y Granada o los obispos de Burgos y Salamanca.

El juicio de legalidad para la aprobación de la obra era realizado por "un Letrado muy fiel y de buena conciencia en la Facultad que fueren los tales libros". Se prohibieron las obras apócrifas, supersticiosas, reprobadas y las que trataran de cosas vanas y sin provecho. Si el informe era favorable la autoridad competente concedía la licencia, pero, una vez impresa, la obra debía volver a ser fiscalizada

1 GARCÍA CUADRADO, A., "Aproximación a los criterios legales en materia de imprenta durante la Edad Moderna en España", Revista General de Información y documentación, vol. 6, N 2, Madrid, 1996, p. 140.

2 Ibidem, p. 142.

3 Esta Pragmática sigue los pasos de la bula Inter Multiplices del papa español Alejandro VI (1501), trasunto de la homónima de Inocencio VIII (1487). El tenor literal de la misma puede encontrarse en ibidem, pp. 140-141. 
por el letrado para verificar que el original no había sufrido modificaciones.

En 1554, Carlos I promulgó en La Coruña una serie de ordenanzas en esta materia con las que trató de corregir los defectos advertidos en el proceso censorio, que habían permitido la publicación de "libros inútiles y sin provecho alguno, y donde se hallan cosas impertinentes" ${ }^{4}$. La principal novedad legislativa fue la centralización de la competencia para la concesión de las licencias de impresión en el Consejo de Castilla, que acabó con la dispersión anterior.

Los reducidos brotes protestantes surgidos en Valladolid y Sevilla en la década de los cincuenta fueron reducidos a cenizas mediante los autos de fe. Estos hechos marginales arreciaron la vesania del mortificado Emperador, que creía estar presenciando la reedición de las revueltas luteranas que habían desmembrado el Sacro Imperio, cuando en realidad jamás hubo en España células protestantes lo suficientemente numerosas y activas como para que entrañaran un riesgo para la ortodoxia católica.

El delirio del retirado monarca lo determinó a escribir el 25 de mayo de 1558 una carta a su hija Juana, regente de España durante la ausencia de Felipe II, en la que le recomienda que ejecute contra la herejía la misma política que él había implementado en Flandes, basada en "proceder contra ellos como contra sediciosos, escandalosos, alborotadores e inquietadores de la república, y que tenían fin de incurrir en caso de rebelión porque no se puedan prevaler de la misericordia (...) se tomó por medio de hazer una orden en que se declarasse todas personas de cualquier estado y condición que fuessen que incurriesen en alguno de los casos allí contenidos, ipso facto fuesen quemados y confiscada su hazienda" ${ }^{5}$.

Las medidas preconizadas en la epístola fueron implementadas por el Inquisidor General Valdés y por Felipe II, que igualaba a su padre en su aversión heterodoxa. El Rey prudente decidió endurecer la calificación jurídica de la herejía: ya no se trataría de un delito contra la divinidad sino contra la seguridad del Estado. Esta modificación abrió la puerta a la represión consagrada en la draconiana Pragmática de 7 de septiembre de 1558, que aherrojó a los mercaderes del libro a un escrupuloso control y a la pena de muerte y a la confiscación de sus bienes en el caso de contravenir sus preceptos:

4 Citado en ibidem, p. 143.

5 AGS, Patronato Real, Inquisición, leg. 28, f. 37, citado por KAMEN, H., La Inquisición española, Madrid, 1985, p. 107. 
"Ningún librero ni mercader de libros ni otra persona alguna, de cualquier estado ni condición que sea, traiga ni meta, ni tenga ni venda ningún libro, ni obra impresa o por imprimir, de las que son vedadas y prohibidas por el Santo Oficio de la Inquisición en qualquier lengua, de cualquier calidad y materia que el tal libro y obra sea so pena de muerte y perdimiento de todos sus bienes, y que los tales libros sean quemados públicamente" ${ }^{\text {. }}$.

El giro extremista de la política de control ideológico-religioso, encaminada a la edificación de una muralla profiláctica frente a la infección luterana que circulaba por Europa, se consumó con la promulgación de la Real Cédula de 1558 que instituyó la vigilancia y supervisión sistemática de las mercancías que entraban por los puertos y la frontera francesa; la Pragmática de 22 de noviembre de 1559, que prohibió a los españoles ser docentes y discentes fuera de los dominios de la Monarquía Católica y el Índice del Inquisidor General Valdés publicado en 1559.

El celo en proteger determinados secretos de Estado que pudieran comprometer los intereses patrios y la inquina hacia la libertad de las plumas que nutrían el odio del pueblo hacia la nobleza -responsable de su misérrima existencia- afilaron la legislación censoria en el Seiscientos.

La principal norma sobre la materia fue la Pragmática de 1627. Felipe IV, buen conocedor de las grietas del sistema de control censorio de los impresos menudos y de la perentoria necesidad de fortalecer el sistema de licencias de impresión, instituyó la figura del Juez de Imprentas ${ }^{7}$, miembro del Consejo de Castilla al que se le encomendó la concesión de licencias sobre los pliegos sueltos.

La Pragmática introdujo en la censura el arbitrario tamiz de la utilidad -"fruto y provecho común"- en orden a prohibir obras triviales o frívolas, sumiendo en la más absoluta indefensión a los autores e impresores. Este nuevo óbice en el iter del libro fue incorporado al Novus Index del Inquisidor General Zapata (1632) y se reiteró en el Novissimus Index de Sotomayor $(1640)^{8}$.

En 1637, el clima político se había enrarecido sobremanera con la apertura de hostilidades contra nuestro vecino del norte y la irrupción de una oleada de literatura afrentosa hacia nuestro país,

6 Citado por GARCÍA CUADRADO, A., op. cit., p. 145.

7 Cfr. ÁLVAREZ GARCÍA, H., "La abolición de los tribunales de imprenta en la Constitución de Cádiz", Revista Española de la Función Consultiva, $\mathrm{N}^{\mathrm{o}} 19,2013$.

8 Cfr. PARDO TOMÁS, J., Ciencia y censura. La Inquisición española y los libros científicos en los siglos XVI y XVII, Madrid, 1991, pp. 102-103. 
propagada por nuestros enemigos que pretendían destruir la grandeza imperial de España.

Ante la complejidad del escenario, el Rey poeta, movido por el deseo de salvaguardar el honor de España y de impedir las filtraciones de información gubernativa que pudieran menoscabar la seguridad del Estado, ordenó al Consejo de Castilla que "no dé licencia y disponga no se imprima ninguna cosa de calidad que toque historia, ni de sucesos dignos de ponerse en ella, sin que se dé primero cuenta desto para que yo mande lo que conviniese, y también pondrá particular cuidado en hacer recoger qualesquier papeles de que tenga noticia que toque a esto"

Según se desprende de la insistencia del monarca, las normas en materia de censura que acataban pero no se cumplían con el escrúpulo exigible y aquélla se efectuaba con ligereza por los censores, perjudicando los intereses del Estado. Así, en 1645, Felipe IV ordenó al Consejo de Castilla que los libros con título de historia o de guerra fueran examinados por los ministros del Consejo de Estado y no se permitiera su publicación sin su aprobación.

Tres años después, en un Auto fechado el 19 de diciembre de 1648 quedó en evidencia la ineficacia de la restrictiva Pragmática de 1627: el Consejo de Castilla amonestó a las autoridades por permitir la publicación de memoriales de méritos y servicios particulares sin licencia. Lo que producía un grave quebranto a la res publica porque trataban sobre materias sensibles -gobierno, regalías, etcétera-, cuya libre divulgación comprometía la seguridad y los intereses de la Monarquía Hispánica, reiterando la competencia del Juez de Imprenta para la concesión de las respectivas licencias:

"Habiéndose entendido que, con pretexto de darle memoriales á S.M., se imprimía sin licencia algunos que, no siendo simples relaciones de servicios, contenían muchas cosas tocantes al Gobierno general y político y á la causa pública, mezclando también la justificación y calificación de Regalías y derechos Reales; se mandó que ninguna persona ni Comunidad, tocando en todo ó parte los dichos memoriales en lo referido, los dé á imprimir, ni los impresores los impriman, sin que preceda mandato y expresa licencia del Ministro Juez Superintendente que tiene a su cargo la comisión de los libros é impresiones; con apercibimiento de proceder contra ellos por todo rigor de Derecho, según lo pida el bien y conservación de estos Reynos: y que el dicho Ministro, à quien han de acudir a pedir licencia, lo haga así

9 DOMÍNGUEZ ORTIZ, A., "La censura de obras históricas en el siglo XVII español”, Chronica Nova, 19, 1991, p. 115. 
executar y cumplir precisamente, de manera que mejor le pareciere y mas convenga" 10 .

El temor regio a los perjuicios e inconvenientes políticos de la libre circulación de las obras bélicas o históricas quedó patente en la lista de objeciones que el Consejo de Estado puso a la obra de Gerónimo Mascarreñas, eclesiástico luso adicto a la monarquía filipina: La campaña de Portugal por la parte de Extremadura el año 1662, publicada al año siguiente, en plena conflagración civil con los territorios lusitanos que luchaban por su independencia de la Monarquía Católica:

"Primero: Que en el citado libro se divulga una comunicación que se envió al gobernador de la plaza de Tánger, que iba a ser entregada a los ingleses, para persuadirle de que no lo hiciera, sino que la pusiera a disposición de la Iglesia católica. Cosa cierta, pero tan secreta que sería de mala consecuencia dejar divulgar estas materias de Estado.

Segundo: Que vitupera la religión anglicana con tan fuertes expresiones que no pueden [los ingleses] dejar de lastimarse de ellas.

Tercero: Que escribe que el rey de Inglaterra se ha casado con una vasalla del rey de España, lo cual, aunque cierto, no será del agrado que se diga.

Cuarto: Que se reprueba la ingratitud del rey inglés por la protección que le prestó España durante su exilio. Y no habiéndosele pedido, ni dado él satisfacción de esta ayuda, parece que subraya un hecho poco satisfactorio para ambas Coronas"11.

Esta serie de datos y opiniones, que fundamentaron su secuestro y prohibición, ponían en serio peligro nuestras relaciones diplomáticas con Inglaterra. La adopción de estas medidas precavía de la posible reacción adversa de los ingleses, en el caso de que el libro llegara a su conocimiento.

La desobediencia de las autoridades a los persistentes mandatos regios, encaminados a garantizar la eficacia de la censura, trajo como resultado que el 11 de enero de 1668, fecha próxima a la independencia de Portugal, se produjera una protesta formal del embajador de Holanda en España por "un papel de D. Juan García Alexandre Castillexo en que discurre largamente el estado en que se hallan al presente las cosas de Portugal, de que han resultados quexas del

10 Citado por GARCÍA CUADRADO, A., op. cit., p. 151.

11 Archivo Histórico Nacional, Consejos, 7289, citado por DOMÍNGUEZ ORTIZ, A., op. cit., pp. 117-118. 
embaxador de Olanda por hablar con desestimación de aquellas Provincias" 12 .

El conjunto de miembros que integraban el aparato censor encargado de ejecutar las disposiciones reales fue impenetrable al desvelo regio por la efectiva vigilancia de las obras de contenido político. La guerra intestina con Portugal constituyó un ejemplo paradigmático ya que fue objeto de una frondosa literatura que fluyó con libertad por España, hasta el punto de que el marqués de Aytona tronó contra la libertad de manifestar en hojas sueltas opiniones sobre la coyuntura bélica en una representación enviada en 1666 a la Reina regente:

"El mayor riesgo en que estamos es la falta de justicia y la desautorización de ella, atreviéndose el pueblo a hablar tan licenciosamente como manifiesta tanta multiplicidad de pasquines contra el gobierno que, aunque de éstos no se ha librado en otros tiempos, aun los más acreditados, pero tantos y con tanta libertad nunca se han visto" 13 .

El celo regio por el respeto a la legislación censoria pretendía también eclipsar la grave crisis que en todos los órdenes padecía el país en aquel tiempo, tratando de imponer un apagón informativo que cloroformizara a la sociedad española. Prueba de ello es la prohibición generalizada de las gacetas el 6 de abril de 1680, incluyéndose La Gaceta, fundada en 1661 y cuya tinta volvería a surcar los pliegos a finales de 1683, y la Real Orden de 8 de mayo de 1682, que reforzó la directriz marcada por la Pragmática de 1627:

"Habiendo reconocido que resultan muchos y muy graves inconvenientes al buen gobierno y conservación de mis dominios, de que se impriman libros, y memoriales y papeles, en que se trate y discurra de ellos o cosa que toque a su constitución universal ni particular por vía de historia, relación, pretensión, representación o advertencia (...) se prohíbe generalmente la impresión de ellos, sin que primero se haya visto por el Consejo á quien tocare el que se hubiere de tratar, y pasado por su censura" ${ }^{14}$.

12 Archivo Histórico Nacional, Consejos, 7178, citado en ibidem, p. 118.

13 Citado por FERNÁNDEZ VALLADARES, M., Catálogo bibliográfico y estudio literario de la sátira política popular madrileña (1690-1788), Madrid, 1988 , p. 88.

${ }_{14}$ Citado por REYES GÓMEZ, F. de los, El libro en España y América, Madrid, 2000, p. 344. 


\section{LA GÉNESIS DE LA OPINIÓN PÚBLICA}

En el Viejo Continente podemos identificar el período que transcurre entre el Renacimiento y la Reforma protestante como la alborada de un inédito vector político: "la opinión de la mayoría"15, que alcanzará un notable ascendiente -límite al poder- en la gestión pública de los monarcas absolutistas.

"Debe, por tanto, quien llegue a príncipe con el favor del pueblo, mantenérselo amigo, cosa fácil ya que el pueblo sólo pide no ser oprimido. Pero uno que contra la voluntad popular llegue a príncipe con el apoyo de los grandes, deberá, ante todo, intentar ganarse al pueblo, lo que será fácil si se convierte en su protector. Y puesto que lo hombres, cuando reciben el bien de quien esperaban mal, se sienten más obligados a su benefactor, recibirá enseguida del pueblo más afecto que si hubiera llegado al principado con su apoyo. Y el príncipe puede ganarse al pueblo de muchas maneras (...) a un príncipe le conviene contar con la amistad de su pueblo, de lo contrario no tendrá remedio alguno en la adversidad" 16 .

Maravall sostiene que "la manifestación de la opinión no es ya, en el siglo XVII, la plaza pública, sino, como corresponde a una época ya tan característicamente moderna, el papel impreso" ${ }^{17}$. Sin embargo, disentimos parcialmente de esta aseveración porque durante el Seiscientos las concurridas y bulliciosas plazas -"corrales del vulgo" (Gracián) ${ }^{18}$-, en las que el público presenciaba atento lecturas de libros ${ }^{19}$, representaciones teatrales, homilías jesuíticas ${ }^{20}$, pu-

15 "Todos ven lo que pareces pero pocos sienten los que eres y esos pocos no se atreven a oponerse a la opinión de la mayoría que tiene además el poder del estado que les protege; y en las acciones de todos los hombres, especialmente de los príncipes, donde no hay tribunal al que apelar, se atiende al resultado" (MAQUIAVELO, El príncipe, XVIII).

16 Ibidem, IX.

17 MARAVALL, J.A., Teoría del Estado en España en el siglo XVII, Madrid, 1944, p. 355 .

18 El Criticón, II, 5.

19 Estaba extendida la figura del lector público en la ciudad y en el campo: “(...) generalmente un hombre -las mujeres leían todavía menosque se prestaba, casi siempre de forma gratuita, a entretener a amigos y vecinos en las veladas, tras el trabajo diario" (DÍAZ-PLAJA, F., La vida cotidiana en la España del Siglo de Oro, Madrid, 1994, p. 225).

Cfr. CERVANTES, M. de, Don Quijote de la Mancha, I, 32.

20 La novedad del sermón en las iglesias tuvo un éxito arrollador entre el público, que abarrotaba los templos hasta el punto de no poder acoger a todos los fieles entusiasmados por escuchar a los predicadores. Su diseño arquitectónico tampoco permitía que todos los presentes visualizaran al orador ni que éste viera al conjunto de los feligreses, de manera que una de las opciones a las que cotidianamente se recurrió hasta que se alteró su 
blicaciones de normas ${ }^{21}$; y los mentideros ${ }^{22}$ eran los espacios en los que el pueblo discutía, se informaba y opinaba, donde se formaba la opinión pública.

En la capital de la Monarquía Hispánica había tres significativos mentideros. El más célebre era el de las Gradas del Convento de San Felipe el Real, situado en la calle Mayor y frecuentado por una abigarrada tipología social, de la que descollaban, por su número y algarabía, los mílites ${ }^{23}$. Las Losas de Palacio estaban en los patios del Real Alcázar. Este mentidero estaba especializado en las informaciones políticas y era el centro neurálgico del nepotismo y de la corrupción sistémica que gangrenaban el cuerpo doliente de la Monarquía Católica ${ }^{24}$. Por último, el mentidero de los representantes, situado en la calle del León en el distrito de Huertas, concitaba a lo más granado de la bohemia artística y literaria del Siglo de Oro español. Allí

estructura -una sola nave- fue el traslado de la arenga teologal a las plazas, lugar predilecto de los jesuitas para evangelizar con sus sermones.

21 "No puede ignorarse cómo, a través de la publicación, las autoridades favorecían las concentraciones y las discusiones colectivas de los ciudadanos que con tantas cautelas trataban de evitar: justamente aquéllas que tenían como centro de atención las decisiones y la conducta de los poderes públicos". Sin embargo, "los castellanos no habrían tolerado la privación de la prerrogativa inmemorial de ser informados en las plazas y de la posibilidad de control sobre las decisiones del poder que tal práctica permitía. Control todo lo simbólico, implícito y oculto que se quiera, pero inseparable de la naturaleza misma de toda adquisición pública y colectiva de noticias (OLIVARI, M., Entre el trono y la opinión. La vida política castellana en los siglos XVI y XVII, Valladolid, 2004, p. 215).

22 "El Mentidero era taller, redacción é imprenta, sin previa censura, ni fiscalía, ni timbre, y con una suscripción tan numerosa que ya la quisieran para sí los periódicos más entonados. La mentira suelta del Mentidero tenía, después de todo, paso franco por todas partes, y no se sabe que jamás diera de bruces con los familiares de la Santa Inquisición" (SEPÚLVEDA, R., Madrid viejo, Madrid, 1996, p. $6)$.

23 " (...) el mentidero de los soldados, de donde salen nuevas primero que los sucesos" (El diablo cojuelo, VIII, Vélez de Guevara).

${ }_{24}$ "Su núcleo principal de clientes formábanlo aspirantes a empleos y mercedes, papelistas y gacetistas, entre quienes la marcha de la cosa pública era tema casi único de conversación. En las puertas de Palacio fijábanse los pasquines, ingeniosos o mordaces, risa de la Corte y escándalo de gentes timoratas; en los rincones de ambos patios concertaban los familiares de ministros y jueces, con pretendientes y litigantes, cohechos y sobornos, ruedas toleradas de la máquina administrativa de entonces, y allí también se adquirían los libelos y papelones anónimos, mandados recoger por la Inquisición o por el presidente de Castilla. En el corro central leíanse los papeles políticos más serios y las gacetas, impresas o manuscritas, y se comentaban luego, junto con las noticias que facilitara la indiscreción o amabilidad de los funcionarios, las que trajera un correo polvoriento, las que vociferara algún soldado de vuelta de la guerra, algún cautivo recién salido de galeras por redención o fuga, y, en fin, las que divulgara, complaciente, la baja servidumbre palatina" (MAURA GAMAZO, G., Carlos II y su Corte, vol. I, Madrid, 1942, pp. 21-22).

(C) UNED. Revista de Derecho UNED, núm. 26, 2020 
se hostigaban con epigramas y departían animados y donosos sobre los enredos amorosos o las nuevas de la farándula española ${ }^{25}$.

Por tanto, fue en las plazas y mentideros donde "se forjó la opinión pública, y las críticas y los ataques contra los abusos y las gentes bien situadas que se expresan allí con frecuencia dan origen a aquellos pasquines -libelos, panfletos, coplas satíricas- que florecen en el siglo XVII"26. Tanto es así que Maravall considera el siglo décimo séptimo como "la edad de los libelos y pasquines. La actividad que los escritores satíricos desarrollan en esta esfera de la política es de gran volumen. En verdaderas batallas de libelos y pasquines luchan los partidos. Recuérdese en el reinado de Carlos II la lucha de panfletos entre los partidarios de Doña María de Austria y el Padre Nithard y los secuaces del díscolo Don Juan de Austria”27.

"El arma de oposición verdaderamente temible era el vago y terrible ambiente que se formaba en la plaza pública y en los mentideros cortesanos con rumores y hablillas, epigramas, versos, libelos y documentos apócrifos que se difundían por todas partes, llegando, conducido por manos invisibles, hasta los mismos aposentos reales. Esta era, en el siglo XVII, "la opinión" eficaz"28.

Juan José de Austria, hijo extramatrimonial de Felipe IV, fue un hombre obsesionado por conocer y controlar la opinión pública, especialmente durante sus años de gobierno en los que realizaba frecuentes excursiones nocturnas: "Hase reparado en un coche de dos mulas parado en diversas calles estas noches; y se ha descubierto ser el Rey, don Juan y Talara, que salen a oír y ver lo que se dice y pasa en los corros acerca del gobierno: acción que ha parecido de poco fondo y cortísima razón de estado, porque si anda el coche, poco o nada se puede oír; y si se para, es reparado; y si hablan del gobierno, todos callarán; porque ninguno quiere ser el que eche el cascabel al gato, ni ser el escarmiento de los demás"29.

25 "Los lujos de la primera dama, que pagaba el aristócrata o coronado protector, haciendo la vista gorda el sufrido esposo; los rigores de la autoridad, moliendo a cómicos e histriones con sus bandos prohibitivos e inútilmente moralizadores; las envidias y emulaciones de las compañías y los comediantes; los apuros de los que andaban tronados; el éxito o el fracaso de la comedia nueva; las esperanzas de la que se iba a estrenar, etc. Se discutía desde la estética teatral y el arte de hacer comedias de Lope, hasta los quilates de hermosura o arte de la cómica de moda" (DELEITO Y PIÑUELA, J., Sólo Madrid es Corte, Madrid, 1962, p. 219).

26 DEFOURNEAUX, M., La vida cotidiana en la España del Siglo de Oro, Barcelona, 1983, p. 69.

27 MARAVALL, J.A., op. cit., p. 355.

28 MARAÑÓN, G., El conde-duque de Olivares, Madrid, 1958, p. 207.

29 Valencia Idiáquez, Diario de noticias, p. 115, citado por AICHINGER, W., "La cara oculta de la opinión pública. Avisos, pasquines y cartas 
Cuarenta años antes, Calderón de la Barca ya había subrayado la preocupación regia por conocer la opinión pública en orden a orientar su acción de gobierno:

Rey. Toda la noche rondé

de aquesta ciudad las calles;

que quiero saber así

sujetos y novedades

de Sevilla, que es lugar

donde cada noche salen

cuentos nuevos y deseo

desta manera informarme

de todo para saber

lo que convenga.

Don Diego. Bien haces;

que el Rey debe ser un argos

en su reino vigilante:

el emblema de aquel cetro

con dos ojos lo declare ${ }^{30}$.

En el Seiscientos el vulgo abandona su tradicional papel de sujeto pasivo e inerme de la política absolutista para convertirse en un arrojado actor, que irrumpe enérgico en la vida política manifestando públicamente su opinión a pesar de la ausencia de libertad y la violenta represión, incapaz de embridar la conciencia y la voluntad humanas ${ }^{31}$. Estamos, pues, siguiendo a Maravall, ante el despuntar de la opinión pública ${ }^{32}$.

interceptadas en la corte española del siglo XVII", Revista del Departamento de Historia, Historia del Arte y Geografía. Facultad de Filosofía y Letras, 2016, Universidad de Navarra, p. 31, nota 41.

30 El médico de su honra, II.

31 "El hombre puede ser atado contra su voluntad, porque puede ser atado sin él quererlo; puede ser atormentado contra su voluntad, porque puede ser atormentado sin él quererlo; pero lo que no puede el hombre es intentar querer contra su voluntad, porque no puede querer sin él quererlo; y todo el que quiere, quiere su propio querer" (San Anselmo, De libero arbitrio, VI, citado por PALACIOS, L.E., Don Quijote y La vida es sueño, Madrid, 1960, p. 45).

Cfr. CERVANTES, M. de, op. cit., II, 49.

32 Cfr. MARAVALL, J.A., op. cit., pp. 321-362.

(C) UNED. Revista de Derecho UNED, núm. 26, 2020 
Sin embargo, en el Barroco español no se consolidó este vocablo sino que son frecuentes las expresiones sinónimas: opinión de todos, opinión de la gente, común opinión u opinión de la mayor parte del ambiente, que se refieren al consensus gentium, al sentir colectivo del pueblo -vulgo y nobleza ${ }^{33}$ - sobre algún asunto de interés público.

La voluntad general que emerge a la esfera pública irradia un poder social de tal magnitud que es capaz de provocar una rebelión civil cuando es hostil hacia los gobernantes. Por lo que la Corona, consciente de la arrolladora fuerza política de la estulta y proteica masa opinante ${ }^{34}$, pero lejos de seguir sus postulados y demandas odi profanum vulgus, et arceo ${ }^{35}$-, está convencida de que "el mundo se gobierna por opinión" 36 ; que "la soberanía entre los hombres consiste en una opinión" 37 - "la grandeza y el poder del rey no está en sí mismo, sino en la voluntad de sus súbditos"38 - y de la notable influencia que ejerce la opinión pública sobre las decisiones políticas gubernativas:

33 "El vulgo, pero también los optimates interpretan la debilidad de fuerzas, la disminución de las riquezas y de los impuestos como un castigo de la ocupación de los bienes de la Iglesia" (MARIANA, J. de, Del rey y de la institución real, I, X).

34 "Y más siendo el vulgo inconstante, que no ay nada más incierto que él; y en la multitud está la variedad; y es tan a menudo la mudança de los pareceres y opiniones como las tempestades; y en los alborotos aunque pocos se atreven a enprender, los más la dessean y todos la consientes" (Biblioteca Nacional, ms. 2374, Sobre la jornada que hiço su magestad a Aragón el año 1642. Por D. Juan Duque de Estrada y Guzmán, citado en GELABERT, J.E., Castilla convulsa (1631-1652), Madrid, 2001, p. 190).

35 "No sólo el príncipe sino nadie debe otorgar nada a la opinión del vulgo, sino volver la espalda a los rumores de un pueblo imbécil" (MARIANA, J. de, op. cit., II, 13).

Cfr. SAAVEDRA FAJARDO, D. de, Idea de un príncipe politico cristiano representado en cien empresas, LXI.

36 "El mundo se gobierna por opinión, y más las cosas de la guerra; con ella se sustentan los imperios; mientras ella está en pie, ellos están; y cayendo ella, caen; y con la reputación muchas veces se acaban más casos que con las armas y con los ejércitos. Y reyes y príncipes poderosos de ninguna cosa deben ser más celosos, después de hacer lo que deben a Dios y a sus reinos, en ninguna más vigilantes y solícitos, que en ganar, conservar y acrecentar esta opinión, y que todo el mundo sepa, que ni ellos quieren hacer agravios, ni consentir que nadie se lo haga a ellos. Porque perdiéndose esta reputación, se pierde mucho; y una vez perdida, con dificultad se torna a recobrar" (RIVADENEYRA, P. de, "Exhortación para los soldados y capitanes que van a esta jornada de Inglaterra, en nombre de su Capitán General", Tratado de la tribulación, Madrid, 1988).

37 LANCINA, J.A. de, Comentarios políticos a los Anales de Tácito, LXXIV, citado por MARAVALL, J.A., op. cit., p. 252.

38 SAAVEDRA FAJARDO, D. de, op. cit., XXXVIII. 
"Por naturaleza influye más en el gobierno y en la vida pública el juicio y la opinión de los hombres que la realidad efectiva de las $\operatorname{cosas}^{\prime \prime}$.

El rey sabe, por tanto, que "no hay monarquía tan poderosa que no la sustente más la opinión que la verdad, más la estimación que la fuerza" ${ }^{40}$. Tiene la obligación de conocerla y de mantener incólume su reputación o crédito ${ }^{41}$ dentro y fuera de sus fronteras para conservar la integridad territorial y el orden público en el Imperio, mediante un ejercicio del poder que no repugne a todo el pueblo ${ }^{42}$.

“[el príncipe] deberá escoger los mejores varones y más ilustres de todo el reino, de quienes se servirá como de sus propios ojos y oídos siempre que no estén inficionados de algún vicio, sino que sean sinceros. A éstos les dará facultad para que no solamente le manifiesten la verdad, sino también todos los rumores maliciosos que el vulgo crea del, pues el dolor que le puedan causar semejantes rumores en su ánimo, lo compensarán con usura la razón de utilidad pública y la salud de todo el reino"43.

"El Rey quiere saber por medio de V.E. la impresión que a hecho en esos naturales, así ecclesiásticos como seculares, las notizias que han benido últimamente de los tratados ajustados entre francia, Ynglaterra y Olanda sobre la succesión y repartizión de esta Monarquía y así ordena a V.E. que con la verdad que acostumbra y con la maior maña y reserva procure V.E. informarse de todo lo referido y del concepto que generalmente se forma de esto, por lo mucho que importa que S.M. se halle con estas notizias ciertas para las resoluciones que combiniese tomar. Dios guarde a V.E. muchos años como deseo, Madrid, 5 de junio de $1700^{\prime 44}$.

39 MARIANA, J. de, op. cit., I, 5.

40 SAAVEDRA FAJARDO, D. de, op. cit., LXXXI.

41 “QQué otra cosa es la reputación sino un ligero espíritu encendido en la opinión de todos, que sustenta derecho el cetro" (ibidem, XXXI).

El efímero valido de Felipe IV, Baltasar de Zúñiga, afirmaba en 1621 que "una monarquía en mi sentir cuando ha perdido la reputación, aunque no haya perdido el estado, será un cielo sin luz: un sol sin rayos; sin espíritu, un cadáver" (citado por ELLIOTT, J.H., El Conde Duque de Olivares y la herencia de Felipe II, Valladolid, 1977, p. 65).

42 En cierta ocasión, Felipe II le dijo al marqués de Mondéjar “que era necesario gouernar de manera, que no se quexassen todos dèl, aludiendo a lo que dixo otro Rey. Forzoso será que los malos nos aborrezcan, lo que à nosotros toca, es proceder, de manera que también no nos aborrezcan los buenos" (PORREÑO, B., Dichos y hechos de el señor Rey don Phelipe Segundo, el Prudente, Sevilla, 1639, p. 65).

43 MARIANA, J. de, op. cit., I, 5.

44 Carta enviada por Antonio de Ubilla a Antonio Ibáñez de la Riva Herrera, arzobispo de Zaragoza, citado por BOUZA, F., Papeles y opinión. Políticas de publicación en el Siglo de Oro, Madrid, 2008, p. 39. 
El poder político del Estado de la Contrarreforma temía que el piélago de libelos y pasquines contra el régimen monárquico-señorial, sembrados en las principales villas y pueblos ${ }^{45}$, y la acción de agentes sediciosos que enconaban a las masas contra el poder-Martínez de Mata disparaba sus arengas en las plazas sevillanas- conformaran una opinión pública hostil hacia el gobierno filipino ${ }^{46}$ que cristalizara -como así ocurrió a lo largo del siglo XVII- en innúmeros motines y revueltas populares contra el régimen monárquico-señorial ${ }^{47}$.

"En Castilla solía ser fácil controlar conciencias, ideas, planes de conspiración más o menos estructurados, pero no las plazas. Por lo general, a las autoridades no se les escapaban en último término las conversaciones reservadas y los discursos más discretos de los súbditos, pero los comportamientos públicos que tenían las calles por teatro y por elemento de cohesión se sustraían fácilmente a su control. Saber mucho pero poder poco no contribuía a la serenidad de los gobernantes, puesto que el desfase falseaba fácilmente su percepción de las dimensiones reales de los peligros: todo da miedo a falta de medios seguros en los que confiar en caso de necesidad"48.

La profusa circulación de panfletos y volantes incendiarios, en los que el texto iba acompañado de una ilustración xilográfica o grabada en cobre para captar la atención del público, no fue un medio de propaganda subversiva exclusivo de España, sino que constituyó un instrumento de persuasión de la opinión pública generalizado en la convulsa Europa del Seiscientos: La Fronda, la Revolución inglesa y la Guerra de los Treinta Años ${ }^{49}$.

45 "Más temen [los príncipes] a los historiadores que a sus enemigos, más a la pluma que al acero" (SAAVEDRA FAJARDO, D. de, op. cit., IV).

"Príncipes: al que no tiene que hacer compradle la ocupación, y con eso compraréis vuestra quietud. Temed al que no tiene otra cosa que hacer sino imaginar y escribir" (QUEVEDO, F. de, "Discurso de todos los diablos, o infierno enmendado").

46 "El vulgo no sabe descubrir una verdad sino seguir una opinión; base donde le llevan y no donde debía de irse" (ZABALETA, J. de, Errores celebrados de la Antigüedad, XXIV).

47 El problema catalán fue uno de los más graves conflictos intestinos que incendiaron el cuerpo imperial durante el reinado de Felipe IV. Sobresalen también las rebeliones independentistas de Portugal (1640), Nápoles (1647) y Flandes (Guerra de los Ochenta Años) y los complots militares de Aragón (1648) y Andalucía (1641). Sólo triunfaron las subversiones portuguesa y flamenca, pero Cataluña y Nápoles llegaron a proclamarse repúblicas independientes durante un breve espacio de tiempo. Asimismo, se produjeron revueltas violentas en diversas ciudades andaluzas, Vizcaya, Palermo, etc.

48 OLIVARI, M., op. cit., p. 210.

49 Cfr. KAMEN, H., El siglo de hierro, Madrid, 1982, pp. 327-337. 
La Monarquía Católica no toleraba la convivencia en la escena pública de ideas políticas reluctantes con el mensaje ideológico oficial, de forma que para impedir que la heterodoxia calara en el vulgo persiguió a los agitadores responsables de empapelar las calles con dicterios contra el gobierno; aceró la censura con la reforma de 1627 y se sirvió de los resortes propagandísticos de la manipulación de masas: el poder la imagen (la Nueva Comedia y las fiestas públicas ${ }^{50}$ ) -penetración sensitiva ${ }^{51}$ - y la predicación religiosa, en orden a ejercer un poderoso influjo psicológico sobre el vulgo que le permitiera encadenarlo bajo su yugo, y así lograr su adhesión emocional al régimen monárquico-señorial.

En suma, nuestros preceptistas barrocos bosquejaron las primeras construcciones doctrinales sobre la opinión pública, en las que ya vislumbraron sus características esenciales: extraordinaria fuerza política; estrecha conexión con la libertad de expresión, determinante de su formación y difusión, y la doble dimensión de la institución, a saber, los súbditos, sujetos activos de la opinión pública, ejercitan la libertad de expresión para guiar u orientar la acción política de los gobernantes ${ }^{52}$; y las decisiones políticas, sujeto pasivo de las críticas del pueblo, derivan en la subsecuente exigencia de

50 “Con la organización de estos festejos -manipulando la admiración y entusiasmo que suscitan- se trata, ciertamente, de distraer al pueblo de sus dificultades, de los reveses, de las pérdidas por las que pasan. Por esa vía se le aturde y se le atrae, empujado por un último sentimiento que surge por detrás del asombro, un sentimiento de adhesión extrarracional hacia los que pueden ordenar tanto esplendor o diversión gozosa. La fiesta, sí, es un divertimento que aturde a los que mandan y a los que obedecen y que a los de abajo les hace creer y a los de arriba les crea la ilusión de que aún queda riqueza y poder, de que el triunfo de la Monarquía y de la sociedad en que se basa no podrá ser arrebatado" (MARAVALL, J. A., Teatro y literatura en la sociedad barroca, Barcelona, 1990, p. 180).

Cfr. DÍEZ BORQUE, J.M., (coord.) Teatro y fiesta del Siglo del Oro en tierras europeas de las Austrias, Madrid, 2003.

51 "Son los ojos, entre los sentidos que sirven al alma, por donde entran y salen muchos afecto" (SUÁREZ DE FIGUEROA, C., Varias noticias importante a la humana comunicación, fol. 244, citado por MARAVALL, J.A., La cultura del Barroco, Madrid, 2008, p. 504).

52 "La elección de representantes no es medio suficiente para asegurar a la nación de que no se harán leyes directas contra ella. Sólo la libertad de imprenta puede lograr esto. Sólo por ella pueden saber los hombres buenos que se hallen en el cuerpo legislativo la opinión de la nación para que formen según ella las leyes, y los malos para que teman ir directamente en contra. Los debates del cuerpo legislativo deben dar tiempo a que la nación se imponga en lo que se trata" (BLANCO WHITE, J.M., El español, NVIII, 1810, pp. 144-145). 
responsabilidad de los cargos públicos: ¡Viva el Rey y muera el mal gobierno! ${ }^{53}$

\section{EL ADOCTRINAMIENTO POPULAR}

El Barroco español es un movimiento cultural promovido desde el Poder para infundir en la opinión pública un sentimiento de íntima comunión emocional con el sistema político absolutista. En palabras de Maravall, el Barroco es "un conjunto de resortes, psicológicamente estudiados y manejados con artificio, para imprimir las líneas de una mentalidad acorde con los intereses de los grupos poderosos, en las capas de población urbana, y, llegado el caso, de población rural" ${ }^{54}$.

Así, con el fin de neutralizar los movimientos sediciosos, soliviantados por la grave crisis alimentaria, social y económica que consumía al país, el Poder cercenó el espíritu renacentista y prohibió el paso a las novedades en aquellas áreas del saber que pudieran espolear la insurgencia contra el régimen monárquico-señorial: política, Derecho, ciencia, religión y filosofía. Sin embargo, fue permisivo con determinadas artes, instrumentalizadas al servicio de la ideología tridentina, como la pintura o la literatura ${ }^{55}$, es decir, adoptó el patrón de conducta propio de los Estados totalitarios.

La Monarquía Hispánica empleó los resortes ideológicos, artísticos y sociales de la cultura del Barroco ${ }^{56}$ para ejercer una influencia psicológica de tal magnitud sobre la masa que le permitiera encadenar su conciencia bajo su yugo, y de esta forma dejara de ser una amenaza para el régimen monárquico-señorial.

53 Arenga de los revolucionarios comuneros que permaneció en el imaginario popular y se convirtió en el lema de las asonadas que jalonaron el Antiguo Régimen.

54 MARAVALL, J.A., La cultura del Barroco, op. cit., p. 154, nota 55.

55 “(...) mientras el «sistema de la Inquisición» en nada obstaba y, por el contrario, incluso favorecía el desarrollo de determinados tipos de literatura, especialmente la barroca, ahogó el de la investigación personal tanto científica como filosófica, siempre un tanto arriesgadas dogmática y teológicamente; por ello, ciertas ramas culturales pudieron seguir viviendo a pesar del cenit inquisitorial" (ALCALÁ, A., Literatura y ciencia ante la Inquisición española, Madrid, 2003, pp. 233-234).

Cfr. MARAVALL, J.A., La cultura del Barroco, op. cit., pp. 455-459.

56 "En la que predominarán, congruentemente, los elementos de atracción, de persuasión, de compromiso con el sistema, a cuya integración defensiva se trata de incorporar a esa masa común que de todas formas es más numerosa que los crecidos grupos privilegiados, y pueden amenazar el orden" (ibidem, p. 89). 
"Todo el arte barroco, de la comedia lopesca, a la novela de Mateo Alemán, a los cuadros de santas de Zurbarán, etc., viene a ser un drama estamental: la gesticulante sumisión del individuo al marco del orden social. Por debajo de argumentos al parecer indiferentes a la cuestión, en obras de muy diferente naturaleza -de Villamediana, de Quevedo, de Gracián, etc.- se mantiene en el fondo la misma temática" ${ }^{\prime \prime}$.

La posición de Maravall y de Díez Borque ${ }^{58}$ es nítida al afirmar el carácter militante de la pléyade de artistas del Siglo de Oro, que gozaron del mecenazgo de la Corona y de los Grandes de España ${ }^{59}$ y prosternaron sus inteligencias ante la ideología del Estado de la Contrarreforma, actuando como adoctrinadores y propagandistas de los valores y principios del régimen absolutista. Lo cual explica por qué la Inquisición no perturbó la eclosión artística del Siglo de Oro.

En una senda adyacente se sitúa Bennasar, que explica la permisividad de la Inquisición con el apogeo de las artes en España con el argumento de que "son creaciones de naturaleza estética: se centran en la belleza formal de la escritura, como en el caso de Góngora, o en la belleza plástica. Exaltan a menudo los ideales de la Contrarreforma, incluso cuando son obra de autores de origen converso. Las obras más profundas, las de Cervantes o de Calderón, aunque expresen un sentimiento trágico de la vida, no discuten, al menos explícitamente, el orden del mundo. Por el contrario, España, tan notablemente situada en la Edad Media gracias a sus contactos con el Oriente musulmán, depositario del pensamiento antiguo y creador también el mismo, estuvo ausente o casi del gran movimiento científico y filosófico del siglo XVII, en el que se renovaron las estructuras del pensamiento, al igual que iba a estar casi ausente de las "aplicaciones” del siglo XVIII. Pensar se había convertido en peligroso, y millares de españoles lo aprendieron a sus expensas"60.

57 Ibidem, p. 90.

58 Cfr. DÍEZ BORQUE, J.M., Sociología de la comedia española del siglo XVII, Madrid, 1976, Parte II.

59 El conde-duque de Olivares a Lope de Vega; el marqués de Sarriá a Calderón de la Barca, Rojas y Góngora; el duque de Sessa a Lope de Vega, el duque de Osuna a Quevedo, etc.,

60 BENNASSAR, B., "Reino del conformismo", en BENNASSAR, B., Inquisición española: poder politico y control social, Barcelona, 1981, p. 340.

(C) UNED. Revista de Derecho UNED, núm. 26, 2020 


\subsection{La Nueva Comedia}

La seña de identidad del teatro del Siglo de Oro fue la Nueva Comedia de Lope de Vega, cuya estela siguieron otros dioses del Olimpo dramatúrgico como Calderón, Tirso, Moreto o Alarcón.

Este nuevo modelo teatral revolucionó las tablas españolas y ganó el aplauso del público postergando a los dramaturgos renacentistas. Así, frente al teatro clásico de temática religiosa y hagiográfica, representado en palacios y dirigido, por tanto, a un reducido público elitista y cultivado ${ }^{61}$, la Nueva Comedia propone en el último cuarto del siglo XVI una inédita forma de hacer teatro que busca conectar con los gustos del vulgo, creciendo geométricamente el número de espectadores en los corrales ${ }^{62}$.

La Iglesia y la Monarquía percibieron de inmediato la utilidad que podía reportarles la comedia lopesca. En plena revolución tridentina, la jerarquía eclesiástica concibió el teatro como un medio de instrucción para formar al pueblo en los misterios sagrados a través de los autos sacramentales, e incluso los jesuitas lo utilizaron pedagógicamente en sus colegios ${ }^{63}$. El Estado, por su parte, advirtió la fuerza propagandística de este medio de comunicación de masas para la divulgación y el adoctrinamiento en la ideología monárquico-señorial, por lo que pugnaron por controlar y dominar este novedoso resorte concebido por el Fénix de los Ingenios.

Aunque el hermanamiento entre la Iglesia y Monarquía Católica era una realidad, ello no significaba que siempre caminaran unidos y que no hubiera fricciones entre ellos, motivadas por una aparente disparidad de intereses más teórica que real. La Iglesia española re-

61 "Si estas [comedias] que ahora se usan, así las imaginadas como las de historia, todas o las más son conocidos disparates y cosas que no llevan pies ni cabeza, y con todo eso, el vulgo las oye con gusto, y las tiene y las aprueba por buenas, estando tan lejos de serlo, y los autores que las componen y los actores que las representan dicen que así han de ser, porque así las quiere el vulgo, y no de otra manera, y que las que llevan traza y siguen la fábula como el arte pide, no sirven sino para cuatro discretos que las entienden, y todos los demás se quedan ayunos de entender su artificio, y que a ellos les está mejor ganar de comer con los muchos, que no opinión con los pocos" (CERVANTES, M. de, op. cit., I, 48).

62 Etimológicamente, el vocablo teatro procede de "la palabra griega théatron (latín theatrum) que deriva del verbo theáomai, "yo miro, soy espectador", y en su origen indicó, sobre todo, la masa de los espectadores y después el lugar en que éstos se reunían para asistir a las representaciones escénicas" (SEGURA MUNGUÍA, S., El teatro en Grecia y Roma, Bilbao, 2001, p. 35).

63 HERMENEGILDO, A., "Norma moral y conveniencia política. La controversia sobre la licitud de la comedia", Revista de Literatura, XLVII, 93, 1985, p. 9. 
chazaba la inmoralidad de las representaciones escénicas, en las que se perpetraban sacrilegios incompatibles con la ortodoxia católica:

"Era tanta la insolencia de estos comediantes en sus comedias que no sólo se contentaban con actuar vestidos de cardenales, obispos, frailes y sacerdotes, ni en mil maneras deshonestas, y en hábitos de misa y con sobrepelliz, sino que esto se ha extendido a los Santos y al mismo Nuestro Señor Jesucristo, poniéndose hombres desnudos en las cruces con mil burlas e infamias y lo que es peor, sus comedias han sido aprobadas por los Diputados que son unos de la Inquisición y Auditores del Consejo, y manifesté esto muchas veces al Sr. Conde de Miranda y al Confesor de Su Majestad, y como no veía más remedio me dirigí finalmente con amonestaciones penales y advertencias de excomunión late sententia a los mismos comediantes diciéndoles que no se atrevieran más, en cualquier lugar donde estuvieran, a llevar las citadas vestimentas, ni representar ni hablar de santos, papas ni de los otros mencionados" 64 .

La presión eclesiástica logró que Felipe II prohibiera las comedias en 1597, lo que desencadenó una confrontación dialéctica entre moralistas y políticos que concluyó con la victoria de estos últimos plasmada en una resolución del Consejo de Castilla de 1600, en la que se autorizó de nuevo las representaciones y se nacionalizó el teatro al arrogarse el control absoluto de las tablas, con lo que se afianzó la preponderancia de los intereses políticos sobre la moral católica hasta $1647^{65}$, año en el que Felipe IV sucumbió ante las presiones de la Iglesia, que imputaba la responsabilidad de las calamidades del Imperio a los desórdenes morales y a la vida disoluta de la sociedad española y de la propia Corona, por lo que para calmar su mala conciencia el Rey poeta decidió prohibirlas; sin embargo, en 1651 volvieron a prevalecer los intereses regios y se derogó la interdicción.

El teatro fue el principal instrumento político de proselitismo del régimen absolutista por "el fuerte impacto que la representación escénica produce sobre la imaginación y los sentimientos de cuantos a aquélla asisten, da lugar a que la expresión del pensamiento cobre en su versión teatral una eficacia mayor, por lo menos momentáneamente, que otras formas de expresión, por ejemplo el impreso"66.

64 Carta enviada por el nuncio de la Santa Sede en la Corte española, Domenico Ginnasi, al cardenal Aldobrandini el 6 de diciembre de 1600. Archivo Secreto Vaticano. Spagna 53 (273), (citado por VARGAS-HIDALGO, R., "Censura teatral en la España de 1600”, Revista de Literatura, LIX, 117, 1997, p. 134).

65 HERMENEGILDO, A., op. cit., p. 18.

66 MARAVALL, J.A., Teatro y literatura..., op. cit., p. 159. 
La escena barroca fue un torrente propagandístico. En los corrales se ofrecían representaciones de historias cotidianas con las que se pretendía solazar al público con músicas, bailes, burlas, enredos, chascarrillos -figura del gracioso- y tramoyas espectaculares que fascinaban a los espectadores, pero en realidad no era más que una almibarada cobertura que disimulaba la firme intención de ahormar y dirigir el pensamiento popular conforme a la ideología oficial.

El proceso alienador dirigido al adoctrinamiento popular fue descrito por Villa de Madrid en el Memorial presentado a Felipe II en 1598, con el fin de mover el ánimo del monarca para que autorizara de nuevo las obras teatrales:

"Conviene que el entendimiento que anda ocupado en cosas graves, alguna vez se afloje la cuerda y desocupe para volverse a ocupar más asentado:

Relajamiento - Estado de indefensión - Recepción de contenidos ideológicos

(afloje la cuerda) (desocupe) (volverse a ocupar)"67.

El vulgo acudía con fruición a disfrutar de las comedias; eran una vía de evasión y esparcimiento de su misérrima existencia cotidiana. El pueblo abarrotaba los corrales con un ansia desmedida por contemplar las tramas y enredos de las obras. Durante su desarrollo experimentaba un torbellino de sentimientos ante el desconocimiento del rumbo de los sucesos dramáticos y taumatúrgicos que iba a deparar la tramoya: "inundaciones, lluvias de fuego, tempestades furiosas, terremotos, o bien aparecían centenares de comparsas en desfile de ejércitos y pasos procesionales" ${ }^{68}$, por lo que la acción sorpresiva e inesperada de los acontecimientos provocaba una confusión de sensaciones -alborozo, aturdimiento, admiración, miedo, etcétera- que abrumaban el alma del espectador:

"Las artes de la mímica, del pintor, del músico, del escenógrafo, y del maquinista, se unen aquí para asaltar a la vez a todos los sentidos, de suerte que el público no pueda escapar"69.

Estos resortes sensoriales eran explotados deliberadamente por los dramaturgos para influir psicológicamente en el espectador, que inmerso en un estado de embeleso estaba inerme ante la propaganda oficialista que se eyectaba desde las tablas en orden a lograr su adhesión irracional al régimen absolutista.

67 Citado por HERMENEGILDO, A., op. cit., p. 11.

68 DELEITO Y PIÑUELA, J., El rey se divierte, Madrid, 1988, p. 226.

69 ALEWYN, L'univers du Baroque, París, 1964, p. 71, citado por MARAVALL, J. A., La cultura del Barroco, op. cit., p. 476. 
"Cuando un madrileño traspasa el umbral de un corral, pierde su calificación en la sociedad en tanto que mercader, sirviente, hijo o hija de familia, aventurera, pícaro; se transforma en espectador, con el mismo título que sus vecinos, y comparte con ellos las mismas exigencias, la misma mentalidad, la misma moralidad del teatro" (Aubrun). "Ello es cierto pero hay que añadir que tal proceder servía para que precisamente, a la salida, cada uno se sintiera más en su propia escala, que tan de acuerdo se juzgaba con la naturaleza y podía funcionar con tanta seguridad"70.

Se encomia el atávico determinismo social en virtud del cual cada persona ocupa en la sociedad jerarquizada el lugar que le ha correspondido por sangre ${ }^{71}$, y se repudia el deseo de ascensión social por matrimonio o riquezas, presagiando la destrucción de España si se sajaban las costuras del inveterado orden social:

Tello el Viejo. ¡Ay, Tello!, la perdición
de las repúblicas causa
el querer hacer los hombres
de sus estados mudanza.
En teniendo el mercader
alguna hacienda, no para
hasta verse caballero
y al más desigual se iguala ${ }^{72}$
Crespo. Dime, por tu vida: ¿hay alguien
que no sepa que yo soy,
si bien limpio de linaje,
hombre llano? No por cierto:
pues ¿qué gano yo en comprarle
una ejecutoria al rey,
si no le compro la sangre?
¿Dirán entonces que soy

$70 \quad$ Ibidem, p. 475.

71 "La sangre es el principio del orden social establecido por la férrea convención de los hombres, pero dado que en la herencia hay un elemento natural y que la naturaleza es obra, o mejor, ministro -como a veces se la llama-de Dios, por esa vía el orden de la sociedad viene a quedar anclado en la voluntad divina, como advierte Calderón (Saber del mal y del bien)" (MARAVALL, J.A., Teatro y literatura..., op. cit., p. 41).

72 Los Tellos de Meneses, I (Lope de Vega). 
mejor que ahora? Es dislate.

Pues ¿qué dirán? Que soy noble

por cinco o seis mil reales.

Y eso es dinero, y no es honra:

que honra no la compra nadie.

(...)

Crespo. Yo no quiero honor postizo,

que el defecto ha de dejarme

en casa. Villanos fueron

mis abuelo y mis padres;

sean villanos mis hijos $^{73}$.

La desigualdad impone en las relaciones amorosas sus propias normas en orden a evitar la ascensión social por vía nupcial, de forma que los amantes sólo eran iguales y, por tanto, podían casarse si pertenecían al mismo estado. Esta norma aseguraba la pureza nobiliaria y contribuía al control social impidiendo la promiscuidad de estamentos, pero por sí sola no hubiera podido alcanzar sus fines si no hubiera contado con la tradicional potestad parental de elegir a los consortes de sus vástagos: "Si todos los que bien se quieren se hubiesen de casar -dijo don Quijote-, quitaríase la elección y jurisdicción a los padres de casar a sus hijos con quien y cuando deben"74.

El teatro barroco apoyó desde la tablas este principio estamental mediante el recurso narrativo de la anagnórisis -presente ya en el teatro clásico español ${ }^{75}$-, en virtud del cual se creaba una historia de enredo en la que inicialmente surgía un amor imposible entre un noble y una villana o una dama y un pechero, pero al final se descubría que la mujer o el hombre eran descendientes de un rey o un aristócrata, con lo que su matrimonio era conforme a las normas sociales, reafirmándose la igualdad en el amor ${ }^{76}$

\footnotetext{
${ }^{73}$ El alcalde de Zalamea, I (Calderón de la Barca).

74 CERVANTES, M. de, op. cit., II, 19.

75 Cfr. Comedia Calamita y Comedia Aquiliana (Torres Naharro), Comedia del viudo y Don Duardos, (Gil Vicente), etc.,

76 Cfr. El perro del hortelano y Contra valor no hay desdicha (Lope de Vega), El vergonzoso en palacio (Tirso de Molina), etcétera. Y en el género novelístico destacan La gitanilla y La ilustre fregona de Cervantes.
} 
La exaltación y veneración de la figura regia era otro argumento recurrente en la Nueva Comedia ${ }^{77}$. Se le presenta como un ser divino, carismático y dechado de virtudes heroicas. Los comediógrafos insisten constantemente en los lazos de unión entre el rey y sus vasallos, por ser un puntal clave en la ideología absolutista para la consolidación y fortalecimiento del orden social.

Dios es justicia ${ }^{78}$, ergo el monarca absolutista que era la encarnación divina en la tierra ${ }^{79}$ y coronaba la sociedad del Antiguo Régimen, representaba la recta justicia del Reino de los Cielos: "Lo que manda el rey nunca es injusto" 80 . La impartición de justicia se convirtió en el principal oficio de los reyes, en el atributo más eminente de su summa postestas:

Rey.

¿Qué es el Rey?

Don Enrique. Justicia81

Condestable. Viene llorando y pidiendo justicia.

Rey.

Hacerla es mi oficio.

Eso significa el cetro82

La Justicia como reina de las virtudes y la imagen del Rey Justiciero estaban perfectamente interiorizadas en la sociedad española desde los Reyes Católicos. No había mejor justicia que aquélla que emanaba del monarca, como lo demuestra la alusión al mismo con el título de maiestas, mayoría o majestad ${ }^{83}$, que evocaba una justicia superior que se fue afianzando progresivamente desde el período bajomedieval y que en el siglo XVII era una realidad incontrovertible, de forma que los territorios de realengo disfrutaron de una justicia de mayor calidad, al ser más imparcial, uniforme y segura que la im-

77 La pintura también contribuyó sobremanera a la deificación de los monarcas absolutistas en la Europa Occidental: Velázquez y Rubens a Felipe IV; Champaigne a Luis XIII, Rigaud a Luis XIV y Van Dyck a Carlos I.

78 "(...) la justicia mira siempre hacia donde nace el sol verdadero, que es Dios y por eso llamaron los santos en las escrituras a nuestro señor Jesucristo sol de Justicia" (Las Siete Partidas, III, I, 1).

${ }_{79}$ "Gila. (...) el rey es Dios en la tierra/ y en lugar suyo, Fernando,/ la justicia representas" (La serrana de la Vera, III, Vélez de Guevara).

"Que es deidad el rey más malo/ en que a Dios se ha de adorar" (El rey Don Pedro en Madrid, III, Lope de Vega).

80 Los pechos privilegiados, II (Ruiz de Alarcón).

81 Lo cierto por lo dudoso, II (Lope de Vega).

${ }^{82}$ El caballero de Olmedo, III (Lope de Vega).

83 TORRES DEL MORAL, A., "Prólogo", en TORRES DEL MORAL, A. et al., Los derechos fundamentales y su protección constitucional, Madrid, 2007, p. 29.

(c) UNED. Revista de Derecho UNED, núm. 26, 2020 
partida por los nobles en sus señoríos, presidida por la arbitrariedad y los abusos:

Rey. Hoy mi justicia dé muestras

que contra insultos y agravios

no hay excepción de personas,

sangres ni deudos cercanos ${ }^{84}$.

Turín. Y así, es justo reparar

que es mejor a toda ley

caer en manos del rey

que de hombre particular ${ }^{85}$.

Lope de Vega en su Arte Nuevo identificó con nitidez cuál era el argumento medular de la Nueva Comedia: "Los casos de la honra son mejores,/ porque mueven con fuerza a toda gente". En la sociedad jerarquizada del Antiguo Régimen hay que diferenciar el honor vertical, entendido como virtud objetiva y heredada que se transmite por la generación y es patrimonio exclusivo de la nobleza; de la honra horizontal, subjetiva y merecida, definida como la dignidad de los súbditos con independencia del estamento al que pertenezcan y reconocida por la sociedad en mérito a sus acciones, de suerte que es la opinión o concepto que los demás tienen de esa persona ${ }^{86}$. Sin embargo, la honra no tenía una dimensión estrictamente individual sino que era un "fenómeno de clan, de estirpe, o de familia, donde la deshonra de uno es también la deshonra de los demás miembros del grupo $^{87}$.

Veinticuatro. ¿Sabes qué es honra?

Rodrigo. Sé que es una cosa que no la tiene el hombre

Veinticuatro. Bien has dicho:

Honra es aquello que consiste en otro.

84 La prudencia en la mujer, III (Tirso de Molina).

85 El saber puede dañar, II (Lope de Vega).

86 "La honra horizontal se refiere a las complejas relaciones entre los miembros de la comunidad en el sentido horizontal del grupo. Tal concepto de honra puede ser definido como fama o reputación y descansaba por entero en la opinión que los demás tuvieran de la persona" (CORREA, G., "El doble aspecto de la honra en el teatro del siglo XVII", Hispanic Review, XXVI, 1958, pp. 100-101).

87 LAITENBERGER, H., "Honra y venganza en el teatro de Calderón de la Barca", en Calderón: testo letterario e testo spettacolo. Atti del $1^{\circ}$ Seminario Internazionale sui Secoli d'Oro, Firenze, 1998, p. 11. 
Ningún hombre es honrado por sí mismo que del otro recibe la honra un hombre.

Veinticuatro. Ser virtuoso un hombre y tener méritos no es ser honrado, pero dar las causas para que los que trata le den honra ${ }^{88}$.

La honra era tributaria de dos principios católicos acrisolados en el Concilio de Trento: la igualdad fundamental de origen -todos somos hijos de Dios- y de fin de los seres humanos -ante el Tribunal de Cristo no hay diferencias-y ninguna virtud sin premio ni crimen impune, pregonados desde las tablas y el púlpito, con los que se pretendió preservar la desigualdad y el privilegio del régimen absolutista.

La honra en el Antiguo Régimen ocupaba el ápice de la jerarquía de valores -"la joya más preciada" ${ }^{89}$ - por encima incluso de la vida, que sólo era digna de ser vivida con honra ${ }^{90}$, por lo que debía aventurarse aquélla en defensa de ésta. Este código de honor conminaba a efectuar acciones resarcitorias en orden a restaurar la fama lacerada, y así recuperar la estima y el reconocimiento social ${ }^{91}$.

En las Comedias de Comendadores se encumbra la justicia material del rey, reparadora de los desmanes de la nobleza y garantía de la armonía y el orden estamental. No se aprecia censura ni reproche alguno al régimen absolutista, sólo se denuncian excesos, comportamientos inmorales y antisociales perpetrados por la baja nobleza aspecto relevante-, con el objeto de acrisolar la sociedad estamental extirpando a los que cometen desafueros contra sus vasallos ${ }^{92}$.

La Nueva Comedia dirige sus versos hacia el plano sensitivo. Así, los vínculos que unen a los súbditos con el monarca son el amor, el temor y la obediencia. Los dramaturgos subrayan con frecuencia la "necesidad de amar al Rey, lo que supone humanizar las relaciones políticas, dirigiéndose la comedia al sentimiento y no a la razón

88 Los Comendadores de Córdoba, III (Lope de Vega).

89 Los Tellos de Meneses, I (Lope de Vega).

90 "Si yo he de procurar quitarte la honra, claro está que te quito la vida, pues el hombre sin honra peor es que un muerto" (CERVANTES, M. de, op. cit., I, 33).

91 Peribáñez: Si en quitarme el honor piensa,/ quitárele yo la vida (Peribáñez y el Comendador de Ocaña, II [Lope de Vega]).

92 Cfr. Los Comendadores de Córdoba, El infanzón de Illescas, El mejor alcalde, el rey, Fuenteovejuna, Peribáñez y el Comendador de Ocaña (Lope de Vega), Del rey abajo, ninguno (Rojas Zorrilla), El alcalde de Zalamea (Calderón de la Barca), etc., 
para favorecer la captación y, sobre todo, la efectividad de lo que se propugna" 93 .

Nuño.

El Rey ha de ser amado.

Rey.

El Rey ha de ser temido.

Nuño.

Temido y amado ha sido

quien mejor ha gobernado,

pero temido no más

no es de legítimos reyes.

Rey. $\quad$ El temor causan las leyes

y el Rey, el amor ${ }^{94}$

Príncipe. ¿Quién es el Rey?

Camilo. Un hombre semideo

que tiene de Dios solo dependencia,

a quien todos le prestan obediencia,

y es única justicia que el bien premia

y que castiga el mal ${ }^{95}$.

"Toda una teoría política que se resume en callar, sufrir y obedecer, sentimientos apoyados en el temor, y que se complementarán en relación directa con el realce de la monarquía- con el amor, con lo que la sumisión del súbdito es total" ${ }^{\prime \prime}$, hasta el punto de que el vasallo no dispone de su propia vida, le es ajena, pertenece a la Corona por lo que en cualquier momento ha de estar dispuesto a entregarla gozoso:

$$
\begin{array}{ll}
\text { Otón. } & \text { Pompeyo, si la salud } \\
& \text { de un príncipe consistiese } \\
& \text { en un vasallo, y tuviese } \\
& \text { honra, nobleza y virtud, } \\
& \text { ¿será justo que luego } \\
& \text { la aventurase por él? }
\end{array}
$$

\footnotetext{
93 DÍEZ BORQUE, J.M., op. cit., p. 152.

94 La primera información, III (Lope de Vega).

95 El saber puede dañar, II (Lope de Vega).

96 DÍEZ BORQUE, J.M., Sociología de la comedia española del siglo XVII, Madrid, 1976, p. 158.
} 
Pompeyo. Habiendo nobleza en él,

salud, vida, honor, sosiego

hijos y patria debería

el vasallo aventurar ${ }^{97}$

Rey. $\quad$ Calle, sufra, obedezca el que desea

vivir en paz, y crea

que aunque ha de ser la Majestad amada

nunca más respetada

que cuando fue temida

todo hombre calle, que le va la vida

porque es la ley más justa de las leyes

callar, servir y obedecer los reyes ${ }^{98}$

\subsection{La predicación religiosa}

"El término barroco resulta útil no sólo para designar una época literaria, sino también un estilo cultural no estrictamente literario. Es útil también en cuanto representa la manifestación cultural del espíritu de la Reforma católica y el absolutismo político"99. En efecto, estamos ante un movimiento poliédrico que rebasa el marco artístico y encierra graves implicaciones religiosas y políticas.

La cultura del Barroco en España produjo un hiato respecto a la renacentista ${ }^{100}$ : sustitución del humanismo antropológico por una espiritualidad trascendente -Dios frente al hombre-; verdad divina versus fueros de la razón; realismo teológico frente utopismo renacentista; memento mori versus carpe diem; fe dogmática versus espíritu crítico, etc.

"Aunque el Barroco en formación recibió el impulso ideológico del jesuitismo español, del Concilio de Trento y, finalmente, del absolutismo francés, supone, en todo caso, un punto de partida italiano,

97 La mayor vitoria, III (Lope de Vega).

98 La Carbonera, I (Lope de Vega).

99 HATZFELD, H., Estudios sobre el Barroco, Madrid, 1972, p. 497.

100 "El Barroco es el medio español de desprenderse del humanismo renacentista" (GARCÍA VILLOSLADA, R., "Humanismo y Contrarreforma o Erasmo y San Ignacio de Loyola”, Razón y Fe, N 121, 1940, p. 23). 
incluso en el terreno ideológico, sobre todo como giro espiritual desde el hedonismo renacentista a los valores religiosos"101.

Las conclusiones del Concilio de Trento configuraron los ejes axiales de la acción pastoral de la Iglesia española de la Contrarreforma: dogmatismo moral y religioso, formación teológica del clero secular, censura libresca y adoctrinamiento popular ${ }^{102}$.

La Iglesia española pretendía cincelar el ideario tridentino en la conciencia del pueblo español. La imposición de la moral católica llevó a la Inquisición a dirigir su férula contra los cristianos viejos, al objeto de reprimir las conductas libertinas sedimentadas en la sociedad española: blasfemias, sacrilegios, vicios, concupiscencia, etcétera.

¿¿Qué importa el blasón honroso de católico?, ¿el título de fieles y que a nuestros enemigos los vituperemos con llamarlos herejes?, pues sólo nos diferenciamos en que ellos son herejes en la fe, nosotros herejes en las costumbres. La disolución de vida en todos los estados, la profanidad en lo eclesiástico, el oprimir los pueblos lo seglar, el desollar los pobres quien tiene por oficio ampararlos, el admitir el cohecho el juez, aceptar personas el poderoso, dar los oficios, las dignidades, no a los méritos, sino a la sangre, al favor, al interés, perder el respeto a los templos, cometer mayores pecados en los días de los mayores santos, tanta usura, robo manifiesto, sensualidad, amancebamiento, ser pecadores y honrarse de serlo, ¿no son obras más de herejes que de católicos?” 103

El cambio cultural impulsado por la Reforma católica fue difundido oralmente en lengua vernácula. Los idiomas españoles fueron el vehículo idóneo para la transmisión del mensaje divino. Empero, el latín no desapareció de la esfera religiosa ya que siguió siendo la lengua oficial de la liturgia católica.

El pueblo español no asimiló la cultura barroca por medio de libros sino por vía oral; se transmitía verbalmente para llegar a toda la población. Esto enseguida lo entendieron los apóstoles de la Contrarreforma: en una sociedad iletrada ${ }^{104}$ la palabra, la retórica, los elementos sensoriales, las imágenes, los símbolos y las representa-

101 HATZFELD, H., op. cit., p. 60.

102 Cfr. JEDIN, H., Historia del Concilio de Trento, Universidad de Navarra, 1981, Tomo IV.

103 SANTIAGO, P. de., Sermón en la traslación del maestro apóstol y capitán de las Españas, Santiago, Madrid, 1632, citado por NEGREDO DEL CERRO F., Los predicadores de Felipe IV, Madrid, 2006, pp. 289-290.

104 En el gozne de los siglos XVI y XVII el 80\% de la población no sabía leer ni escribir (NADAL, J., La población española (Siglos XVI- XX), Barcelona, 1991, p. 17). 
ciones - "books for the unlearned"105- se convierten en poderosas armas de dominación de masas.

La catequesis fue un conspicuo resorte para la instrucción religiosa del pueblo español. Era impartida por el clero dentro de la misa -sermón- y fuera de ella en la administración de los sacramentos e incluso por el maestro de primeras letras de las villas, y sus destinatarios eran tanto niños, como jóvenes y mayores:

"Enseñar a los niños no sólo a leer bien, a escribir y a contar, sino también buenas costumbres y prácticas, haciéndoles oír misa los días de precepto y también el sermón, y rezar el Rosario y confesar en los principales días de fiesta; y que no juren ni peleen ni blasfemen, y que obedezcan a sus padres... y enseñarles el catecismo, y para que haya más uniformidad todos deben usar el catecismo del padre Ledesma, y hacerles leer libros buenos y devotos y no permitir que lean libros de amor ni de cosas profanas" ${ }^{106}$.

En su labor de inculcar el ideario ideológico contrarreformista, los predicadores, además de ejercitar con agudeza la escenificación y el arte de la retórica ${ }^{107}$, se auxiliaron de un arsenal simbólico y sensitivo de gran valor plástico que coadyuvó sobremanera a ganarse las conciencias cautivas del auditorio:

"Juan de Ávila consideraba útil para adoctrinar a la gente de los pueblos que los predicadores y misioneros llevaran no sólo rosarios, cartillas y libros devotos como los de fray Luis de Granada sino también algunas imágenes del santo crucifijo y Nuestra Señora, y San Juan, para que las diesen a los pobres, poniéndoles algunas imágenes en las casas...Y los pueblos han menester de todas estas salsas para

105 SWANSON, R. N., Religion and Devotion in Europe, c. 1215-1515, 1995, p. 161, citado por TORO PASCUA, M. I., "Las falsas reliquias en la literatura española del Siglo de Oro: a propósito de la polémica erasmistas”, Via spiritus, N ${ }^{\circ}$ 8, 2001, p. 223.

106 Programa establecido por el obispo de Coloma de Barcelona en 1600. Archivo Diocesano de Barcelona: Comunium, vol. 72 f.65, citado por KAMEN, H., Cambio cultural en la sociedad del Siglo del Oro, Madrid, 1998, p. 330.

107 "La segregación del púlpito del altar, promovida en el siglo XIII por las órdenes de predicadores, es claro exponente de la necesidad de distinguir el espacio profano de otro sagrado. Mientras que los gestos del sacerdote en los actos litúrgicos están estrictamente reglamentados por el ritual, la eficacia de las acciones del predicador en el púlpito están libradas a su talento artístico. La composición del texto es un hecho literario por más que los materiales provengan en su mayoría de la cantera del Nuevo y Viejo Testamento, pero poco o nada estableció la Iglesia respecto del modo de inducirles vida" (ESTEPA, L., "Elementos dramáticos en varios sermones a fines del siglo XVI", en HUERTA CALVO, J. et al., El teatro español a fines del siglo XVII. Historia, cultura y teatro en la España de Carlos II. vol. III, Amsterdam, 1989, vol. I, p. 166).

(C) UNED. Revista de Derecho UNED, núm. 26, 2020 
comer su manjar: rosarios, imágenes han de ser muchas; y los ricos cómprenlos de las ciudades" 108 .

$\mathrm{El}$ arte sacro y las reliquias poseen un gran valor religioso por su capacidad de prender la llama de la exaltación religiosa de los fieles por medio de su contemplación devota. Desde la noche de los tiempos, la Iglesia primitiva los empleaba para atraer a los creyentes a la unión con Cristo mediante la oración y la meditación, y también como herramienta complementaria en el aleccionamiento de las almas.

En este sentido, el valor de las reliquias era superior al de las manifestaciones del arte sacro porque "de su contacto con la materialidad de Cristo, la Virgen y los santos, se han hecho partícipe de sus méritos y por ello de la gracia divina. Las reliquias resultan ser, por tanto, materializaciones sensibles, localizadas y concretas de una epifanía, manifestaciones de una presencia divina que ofrecen la posibilidad de tocar, ver e incluso oler lo sobrenatural"109.

Este poder religioso implicó que a la Iglesia le resultara indiferente la falsificación y el tráfico de reliquias, desarrollado profusamente desde la Edad Media. A pesar del riesgo de caer en el pecado de idolatría, carecía de relevancia que las personas veneraran piezas falsas, lo que interesaba era que cumplieran su misión: tallar las dúctiles mentes del vulgo conforme el credo tridentino.

El sermón fue el vehículo comunicativo más fértil para la difusión del ideario ideológico-religioso del Estado de la Contrarreforma. Los hombres del púlpito demonizaban la heterodoxia y el individualismo crítico. Se pretendía la comunión irracional de la masa con la cosmovisión cristocéntrica, por lo que exhortaban al pueblo a no pensar: "No tiene el hombre cabeza para andar por alturas (intelectuales) por el grave riesgo que corre de desvanecerse y andársele la cabeza y caer" 110 .

La Reforma católica impuso la obligación de pronunciar sermones durante la misa. Sin embargo, esta obligación era frecuentemente desatendida por el clero secular debido a su precaria formación teológica, por lo que la declamación recayó sobre los predicadores errantes del clero regular.

108 CARO BAROJA, J., Las formas complejas de la vida religiosa (Religión, sociedad y carácter en la España de los siglos XVI y XVII), Madrid, 1995, p. 150.

109 BOUZA ÁLVAREZ, J.L., Religiosidad contrarreformista y cultura simbólica del Barroco, Madrid, 1990, p. 42.

110 AGUADO, F., "Domingo primero de Cuaresma", en Sermones de Adviento y Cuaresma..., p.168, citado por NEGREDO DEL CERRO, F., op. cit., p. 263. 
Las órdenes religiosas se especializaron en este instrumento de control del pensamiento y se esforzaron en formar convenientemente a una miríada de oradores en el arte de la retórica, los clásicos latinos y los comentaristas bíblicos. Franciscanos, dominicos, jesuitas y demás congregaciones de menor entidad diseminaban a sus predicadores en misiones por los pueblos y villas o los enviaban ex profeso con ocasión de la celebración de importantes festividades.

"Grande temeridad sería subirse al púlpito sin haber, y muy bien, estudiado. Y no están muy lejos de ser temerarios los que, confiados en el largo uso, con poco estudio, y menos ocasión osan subirse a hablar a un pueblo entero que lo está escuchando una hora y tan callado que ni aun escupiendo hagan ruido"111.

La novedad del sermón en las iglesias tuvo un éxito arrollador entre los fieles que abarrotaban los templos hasta el punto de no poder acogerlos a todos. Su vetusto diseño arquitectónico tampoco permitía que toda la feligresía visualizara al predicador, de manera que una de las soluciones que se adoptó hasta que se alteró su estructura -una sola nave- fue el traslado de la arenga teologal a las calles y plazas, lugar predilecto de los jesuitas para la evangelización: "Otro padre ha predicado a la puerta de la mar donde se ha juntado en cada sermón más de tres mil animas, porque han sido en fiestas en la tarde y sale allí gran parte de Barcelona"112.

La Compañía de Jesús realizó un formidable trabajo proselitista. Su legión de predicadores sembró los pueblos y villas de España de actos propagandísticos de la Contrarreforma sutilmente escenificados, en los que derramaba la doctrina y la moral tridentina con una retórica pragmática y efectista.

"Declarar la letra del Evangelio; presentar la doctrina sólida; enseñar bien lo concerniente al cumplimiento de los mandamientos; plantar virtudes; arrancar vicios.

No reprender a las autoridades públicamente porque reprenderlas de esa manera hace a la gente común perder el respeto a sus superiores.

Reprender firmemente el vicio de la sensualidad, el concubinato, las mujeres en las calles, y también ahora exhortar a los que viven separados que regresen a la vida conyugal.

Reprender las casas de juego; reprender el exceso en el vestir tanto de los hombres como de las mujeres y especialmente de los ca-

111 SALUCIO, A., Avisos para los predicadores del Santo Evangelio, Barcelona, 1959, citado en ibidem, p. 71.

112 Jaime Puellas Laínez, 31 de agosto de 1561, Archivum Romanum Societatis Iesu, Roma, vol. 98 f. 283, citado por KAMEN, H., Cambio cultural..., op. cit., p. 358.

(C) UNED. Revista de Derecho UNED, núm. 26, 2020 
balleros y de los mercaderes; reprender las farsas y comedias por considerarlas dañinas y advertir a los curas que no asistan a ellas; reprender el abuso en Barcelona de los torneos"113.

Los hombres del púlpito tronaban contra el mundo sensible, grávido de pecados, concupiscencia y corrupción, que degradaba la condición humana y condenaba al hombre a la perdición de su alma.

“¿Qué cosa es el mundo sino sentina de deshonestidad, oficina de maldades, camino de ira, escuela de engaños, muerte de vivos, infierno de muertos, fuente de dolores, pozo de odios, lago de envidia, cadena de costumbre, canto de sirena, mordedura peligrosísima, edificio inestable, fundamento podrido, movimiento sin fin, rueda que siempre corre, falaz amistad, lisonjeros engaños, disimulada virtud, escusada malicia, fraude loada, grato frenesí, honrada vergüenza, velada ignorancia, pomposa vanidad, peligrosa tentación (...) ¡Oh mundo!, siempre degeneraste de Cristo, bienaventurado quien de ti huye" 114 .

Las prédicas no incitaban al vulgo a reaccionar frente a las devastadoras injusticias sociales que señoreaban las asimétricas relaciones sociales, sino al inmovilismo y a resignarse con el lugar que a cada uno le ha correspondido en la sociedad ${ }^{115}$, creada por el $\mathrm{Al}$ tísimo, de modo que violentarla era atentar contra Dios, contra su obra, lo que implicaba un delito de lesa divinitatis.

Desde los ambones se consolaba y alentaba a los fieles para que perseveraran en la fe cristiana y conservaran la esperanza de que Dios en la vida eterna les concedería una mejor fortuna. Los oradores eclesiásticos alentaban la mansedumbre ante las misérrimas condiciones de vida y anatematizaban las riquezas provenientes del sistema precapitalista, pero no porque abogaran por un sistema comunitario o colectivista, sino porque el auge de la burguesía y del comercio de bienes desarrollado durante el Renacimiento permitió una cierta movilidad social que erosionó la rígida sociedad estamental. Pretendían cercenar esta vía de ascensión social ya que pertur-

113 ROVIROLA, R. de, Punts per a predicadors, 1588, citado en ibidem, pp. 337338.

114 PERAZA, M. de, Segundo tomo de sermones quadragesimales y de la Resurrección, Salamanca, 1604, fol. 174r y 175v, citado por NEGREDO DEL CERRO, F., op. cit., pp. 275-276.

115 "Guarde cada uno su lugar para que se conserve agradable la armonía; no se confundan los oficios y los puestos, que en introduciéndose a los que no son propios, se siguen populares desconciertos" (MENDO, A., Príncipe perfecto y ministros ajustados. Documentos políticos y morales, Salamanca, 1657, p. 49, citado en ibidem, pp. 321-322). 
baba el orden jerárquico tradicional determinado por Dios, garante de la tranquilidad pública.

\section{CONCLUSIONES}

En la España de los Austrias el pueblo irrumpe con determinación -en ocasiones violenta- en la vida política manifestando públicamente sus demandas a pesar de la ausencia de libertad. Estamos, pues, ante el despuntar de la opinión pública. La Corona, consciente de que la fuerza política de la voluble masa opinante impedía domeñarla manu militari, consideró necesario adoctrinar al vulgo mediante la inoculación de la ideología contrarreformista a través de los resortes ideológicos, artísticos y sociales de la cultura del $\mathrm{Ba}-$ rroco.

La pléyade de autores del Siglo de Oro realizó una labor impagable al servicio de la propaganda del Estado Absolutista de la Contrarreforma. Sus más talentosos representantes fueron dúctiles pregoneros cesáreos de la ideología monárquico-señorial con la que aleccionaron al pueblo español para que acatara con mansedumbre un orden político-social venal e injusto, basado en el privilegio y la molicie de unos pocos a costa de la miseria de la inmensa mayoría.

Nuestros preceptistas barrocos forjaron las primeras construcciones doctrinales sobre la opinión pública, en las que ya apuntaron sus características esenciales: extraordinaria fuerza política y nítida conexión con la libertad de expresión y señalaron los dos vectores de la institución: los súbditos, que ejercitan la libertad de expresión en orden a guiar u orientar la acción de gobierno, y las decisiones políticas, objeto de las críticas del pueblo, desembocan en la subsecuente exigencia de responsabilidad de los cargos públicos. 
